\title{
Globalization of Science and Technology through Research and Development
}

\author{
Aqueil Ahmad \\ School of Management, Walden University, Minneapolis, USA \\ Email: Aqueil.Ahmad@email.waldenu.edu
}

Received 18 February 2014; revised 23 March 2014; accepted 31 March 2014

Copyright @ 2014 by author and Scientific Research Publishing Inc.

This work is licensed under the Creative Commons Attribution International License (CC BY). http://creativecommons.org/licenses/by/4.0/

(c) (i) Open Access

\begin{abstract}
Globalization of science and technology is an integral aspect of globalization per se. The main engine of globalization is assumed to be the global economy propelled by global trade and technology transfers, the latter as aspects of globalization of science and technology. International trade and technology transfers are the engines that drive global economy. Much has been written on these drivers but relatively little on what drives globalization of science and technology which constitutes the backbone of international technology transfers. I attempt to fill this knowledge gap by suggesting that the drivers behind globalization of science and technology are the emerging global centers of collaborative research and development (R\&D) as constituents of the global invisible college(s). "Science" throughout this article means both science and technology as the two closely related aspects of the same knowledge system.
\end{abstract}

\section{Keywords}

Globalization; Global Invisible College(s); Knowledge System; Science and Technology; Research and Development

\section{Introduction}

It is now generally recognized that all modern economies are part of the world or global economy in small or large measures, one way or the other. Less recognized is the nature of globalization of science and technology, even less the means and mechanisms through which they are being rapidly globalized. I intend to address this problem in the following pages. Historians of science have long recognized cumulative development of knowledge, including scientific and technical knowledge, through interaction of cultures over the millennia [1] [2]. What sets the modern science apart is its breadth, depth, dissemination, and application on a wider and faster scale unimagined in the earlier periods [3]. Science and technology together have become in one package the 
driver, the medium, and the message of the modern globalizing age. This discourse is about what drives globalization of science and technology themselves: the processes of research and development occurring in countless collaborative teams of scientists and engineers on a world scale.

\section{Literature Review}

In the eloquent phraseology of Derek de Solla Price [4], "Science since Babylon," modern science and technology have their antecedents in the historical development of ideas from antiquity to the present times. For Joseph Needham [5], scientific ideas from China flowed to Europe prior to the Industrial Revolution. In his Atlas of the Islamic World, Francis Robinson [6] suggests that the Moorish renaissance in Spain ( $8^{\text {th }}$ through $16^{\text {th }}$ centuries) lit the torch that led to the Renaissance and Reformation in Europe.

In the ancient period, Mesopotamians built Babylon, Indians invented the decimal system, Egyptians built the pyramids, Chinese built the Great Wall, Greeks excelled in logical reasoning, and the Incas invented the most sophisticated calendars. Knowledge that informed these magnificent human achievements was slowly disseminated among half a dozen or so ancient civilizations. For thousands of years, scientific knowledge and creativity remained confined to these exclusive culture areas. Another thousand or so years down the road, these "cradles of civilizations" faded into history. Most among them were downgraded as the poor developing regions or countries at best; others simply as the backward "third world" [7]-[9].

Through successive social, political, and cultural upheavals during the Moorish Spain, the European Renaissance and Reformation, the Industrial Revolution, and the colonial period, the world slowly entered the new age of global science and technology developments. It started in Western Europe and reached the shores of North America relatively quickly in a span of not more than one hundred or so years during the $19^{\text {th }}$ and $20^{\text {th }}$ centuries. A few pockets of scientific resurgence occurred in the decades of the 1970s and the 1980s among the newly industrializing nations in Asia and Latin America, notably in the two from the ancient civilizations noted aboveChina and India. A significant aspect of this development was the beginning of global multilateral movement of scientific knowledge to replace the erstwhile restricted movements between Europe and America-the so-called core, and from there to the less developed technology starved peripheral nations [10]. That was the beginning of the emerging global scientific estate. This discussion focuses on the driving force behind what is now commonly known as globalization of science and technology through globalization of research and development [1].

\section{The Contemporary Scientific Estate}

Contemporary science and technology developments are marked by multidirectional flows of knowledge through the movement of scientific ideas and workers on a world scale. A quick look at any major institute of advanced studies anywhere in the world would testify to the presence of scholars, scientists, and engineers from diverse cultural and geographic boundaries working together as team members. Unlike religion and political ideologies, science today is the greatest unifier of humanity and in many ways the healer of life and strife on earth as well.

Early examples of international joint research projects in the modern period are found in weapons development programs during and after the Second World War; the most notable and unfortunate example being the development of atomic bomb through the Manhattan Project. This project was carried out by a secret team of about half a dozen nuclear physicists from the United States, UK, and France. Years later, it was followed by a nobler and gentler example of science in the discovery of basic structure of the DNA molecule in 1953 in the form of a double helix through a joint research project by two American and English physiologists, James Watson and Francis Crick for which they received a Noble Prize in 1962 [11]. The discovery of double helix was the precursor of the multinational "big science" research, the Human Genome Project (HGP) supported by scientific and financial resources from six different countries. The HGP was jointly launched in 1990 by the United States Department of Energy and the US Department of Health; to be soon supplemented by private and public resources from half a dozen or more countries [12].

Other notable examples of globalization of science and technology on a big scale include space research, AIDS and malaria research, International Crop Research in Semi-Tropical Arid Zones (ICRISAT), the International Rice Research Institute (IRRI) in Manila, and physics at CERN in Geneva, Switzerland. Like the ICRISAT, IRRI is also anon governmental organization (NGO) with offices in 19 countries involving local and international scientists to help develop environmentally sensitive and inexpensive rice cultivation methods, par- 
ticularly for the benefit of medium to small-scale farmers.

Established in 1954, the nuclear research laboratory at CERN is currently the most outstanding example of globalization of science through research and development. The organization is formed by 20 European nations. It employs 2400 full-time and 1500 part-time scientists, engineer and technician from all over Europe. CERN has also hosted 10,000 visiting scientists and engineers, representing 608 universities and research institutions from 113 nationalities. The recent discovery of Higgs Boson was made at the Large Hadron Collider at CERNan awesome and supposedly the most complex machine ever built by human hands [13].

Following the Russian Sputnik (1957) and the American moon landing (1969), space research today is truly a multinational effort that includes participants and contributions not only from Europe and America but also from the newly emerging scientific estates as well. Space station Mir is run by the United States and Russian scientists. A Chinese scientist has already circled the earth. Its Jade Rabbit rover landed on moon on Dec. 14, 2014. It is still there, active again after a period inactivity. Other such space explorations are also planned by China. India recently launched its first Mars mission. Now private entrepreneurs from America, Russia, and Britain are entering the race into space exploration. Science and technology are being globalized through globalization of research, and vice versa. In the age of Internet, there is no classified knowledge anymore. For the frontline innovator, this may be frustrating, even costly; but for the imitators and adapters, not-so-disguised a blessing, for they can learn "secrets of science" sooner or later from the published literature or piracy and espionage.

I argue in this paper that the rising cost of research, cross-cultural movement of scientists and engineers, the power of Diasporas, and above all the forces of globalization like the global economy and competition for markets, materials, and manpower are propelling international cooperation in science and technology explorations. They are expected to continue to do so at a faster pace in all fields and levels of scientific activity in the foreseeable future. Scientific networking in the real or virtual space is now the secret of innovation and development and consequently, that of the rise and fall of nations. Any nation, big or small, would retract its political and financial commitment to research and innovation at its own peril.

\section{The Global Invisible College(s)}

The main plank of this discourse on globalization of science and technology through collaborative global R\&D networks is the concept of global invisible college (or colleges). The initial idea of invisible college goes back to the $17^{\text {th }}$ century Royal Society whereby a selected group of scientists and philosophers in prestigious European academies shared their research interests and discoveries among themselves mostly through letters and/or communications in scientific journals. In a little path breaking book, Little science, big science, physicist and philosopher of science, Derek de Solla Price [14] popularized the concept of a much broader invisible college as the means for generating and accelerating the pace of scientific knowledge in the post WW II period. Price defined the invisible college as informal gatherings of, or written communications among, a larger pool of distinguished scientists to share their research ideas representing, in a way, an exclusive club of the scientific elite. The "club" is, however, no longer either small or exclusive. The invisible college of the $17^{\text {th }}$ century Royal Society, or that of Price's construction relevant to the mid- $20^{\text {th }}$ century, is to be redefined in the context of contemporary nature of both big and small science as the global invisible college (or colleges) involving large numbers of scientific workers in ever increasing global networks of joint research projects such as those cited above. Much of doctoral research in American and European colleges and universities today involves international students, who often become co-authors with their supervisors. Joint authorship of scientific papers is today the norm rather than exception:

Two-thirds of all science and engineering (S\&E) articles in 2010 were coauthored. Coauthored articles grew from $40 \%$ of the world's total S\&E articles in 1988 to $67 \%$ in 2010. Articles with only domestic coauthors increased from 32\% of all articles in 1988 to $43 \%$ in 2010. Internationally coauthored articles grew from $8 \%$ to $24 \%$ over the same period. U.S.-based researchers were coauthors of $43 \%$ of the world's total internationally coauthored articles in 2010. (http://www.nsf.gov/statistics/seind12/c5/c5h.htm\#s5).

The same trend is visible in the production of patents as well. Furthermore, approximately fifty percent of the current membership in major scientific and professional associations in Europe and America, and participation in conferences organized by them, is truly international. Such cross-cultural exchange of knowledge on a global scale is augmented by the fact that the lingua franca of global scientific communication both in the virtual and 
real worlds is English. All international conferences, even in non-English speaking countries, are conducted in English. Almost all scientific work is published, translated, or uploaded in English (National Science Foundation, Science and Engineering Indicators, 2012). All of these activities involving international teams point in the direction of increasing globalization of scientific knowledge generation and transfer on a colossal scale unprecedented in human history.

Globalization of knowledge generation is aided and abetted by the rapidly shifting nature of international scientific communities. The global brain trust balance is gradually shifting in favor of the newly emerging economies. For example, in sheer numbers the combined production of qualified scientists and engineers (QSEs) in China and India surpasses the United States in approx. 4:1 ratio: US = 85,000; India = 103,500; China = 293,000. Ever larger numbers of Indian and Chinese QSEs are flooding the global market for talent every year, close to half a million from India alone. Scientific workers from South Korea, Taiwan, and some Latin and African countries are also joining this global brain trust. Some of them stay home to benefit from R\&D dollars spent overseas by international research organizations or multinational corporations (MNCs). Others migrate to foreign lands in Europe, the United States, and Canada or stay there for some time after getting higher education degrees. In 2009, 87,000+ doctoral and 85,000+ Master's level science and engineering foreign students were enrolled in American higher education institutions (http://www.nsf.gov/statistics/inbrief/nsf10324/\#CGS). How many of them would have actually remained in the country permanently or semi-permanently after finishing their degrees is not known. It, is however, understood that almost of all them contributed to America's brain trust in varying degrees through their in-house education and research.

The brain trust shift is also largely responsible for another highly significant development in globalization of science and technology through research and development. It involves off shoring of corporate R\&D from the talent deficient developed countries to the talent-surplus newly emerging economies of China, India, South Korea, Singapore, Hong Kong, and Taiwan. The overseas R\&D expenditure by the American MNCs has been gradually shifting toward these Asian markets, from 11\% in 1998 to 20\% a decade later. Given the wide difference between the cost of living and wage structures in the developed and the developing countries, the cost of hiring a qualified scientist and engineer in Europe and America is approximately ten times higher than a similar hire in India, for example. Time and language differences in these geographic zones could indeed be negative factors for constructing and working with offshore research teams. But instant communications technologies like the Internet tend to largely overcome these obstacles. Mindful of these advantages, American corporations in 2008 invested approximately $\$ 60$ billion (21\% of \$290) for corporate R\&D in their foreign facilities involving locally trained scientists and engineers. This trend is likely to continue indefinitely.

(http://www.nsf.gov/statistics/inbrief/nsf10322)

\section{Lopsided Invisible College(s)}

The central promise or expectation of global economy was to lift all boats together, to narrow economic inequalities if not eliminate them altogether. Obviously, that has not happened despite some improvements. Ten percent of the world's population still lives on one dollar a day; about half of it lives on less than $\$ 2.50$ a day; $80 \%$ lives on \$10.00 a day-a pitiable record of inequality (World Bank Development Indicators, 2012). These inequalities are duly reflected in the infrastructural development and distribution of scientific knowledge as well. The global invisible college(s) leaves out from the mainstreams of science substantial portions of scientific communities where the broadband and Internet penetration is minimal-less than $5 \%$ of national populations, such as in Afghanistan and Bangladesh in Asia, Cameroon and Congo in Africa, and the Central American and Caribbean regions in the Americas. (Internet World Statistics: www.internetworldstats.com/stats1.htm)

Although the digital divide is narrowing, the situation is best described as "half-way home and a long way to go.” The global economic inequality is also equally reflected in R\&D investments in the poor countries as well. Seventy-five percent of the world's R\&D expenditure is made in the United States (35\%), Europe (27\%), and Japan (13\%). The rest is distributed among the rest of the world; approximately $0.1 \%$ to $1.0 \%$ of it in each of the least-to-moderately developed country in Asia, Africa, and Latin America (UNESCO Institute of Statistics, Fact Sheet 2011, No.15 (http://www.uis.unesco.org/FactSheats). The state of global science and engineering education appears equally lopsided and disturbing. Data on these branches of higher education in poor countries are lacking. The situation can, however, be inferred from the percentage of their meagre GDPs invested on general higher education in some of the least developed countries, such as Cameroon-3.2\%, Burkina Faso-3.4\%, El 
Salvador-3.4\%, and Liberia-2.8\%. (http://data.worldbank.org/indicator\#topic-14)

These inequalities are the primary reasons for keeping large chunks of scientific communities around the world from participating in the global invisible college(s) and contributing to the globalization of science and technology through research and development. Removing these inequalities should be the responsibility of local governments and international development agencies to make the scientific estate truly global.

\section{Conclusion}

We are living in a globalizing age where everything, almost everything, from politics to crimes, cultures, economies, the environment, knowledge, and knowledge transfers are becoming increasingly interconnected on a scale unprecedented in human history. Starting with science and technology as the driving forces for economic globalization - a topic much discussed in my earlier works, the focus in this paper shifted to what may constitute the drivers behind globalization of science technology themselves; that is, the ever-increasing networks of collaborative research and development $(\mathrm{R} \& \mathrm{D})$ activities among scientific institutions and workers spread across the world. Informed by the seminal works of physicist and philosopher of science Derek de Solla Price in the 1960s, these networks are defined as invisible global college(s) through which scientific institutions and workers in distant parts of the world connect with each other in common pursuits of knowledge now aided and abetted by the modern information technologies, notably the internet and the emails. The paper ends with a note of caution about the lop-sided nature of invisible college(s) that leaves out from the mainstream large bodies of scientific communities in less-developed countries with less than adequate facilities for R\&D activities and broadband penetration that tend to directly or indirectly further accentuate global economic inequalities. The policy implications for world governments, nongovernmental economic development agencies, and the United Nations should be obvious in view of these unsettling scenarios of the future of globalization of R\&D, science and technology, the economy, and worldwide positive social change to lift all boats.

\section{References}

[1] Ahmad, A. (2013) New Age Globalization: Meaning and Metaphors. Palgrave Macmillan, New York. http://dx.doi.org/10.1057/9781137319494

[2] Chandra, N. (2007) Bound Together. Yale University Press, New Haven.

[3] Basalla, G. (1968) The Rise of Modern Science: External and Internal Factors. Heath, Lexington.

[4] de Solla Price, D.J. (1961) Science Since Babylon. Yale University Press, New Haven.

[5] Needham, J. (1990) A Selection from the Writings of Joseph Needham. Book Guild, Lewes.

[6] Robinson, F. (1984) Atlas of the Islamic World. Equinox, Oxford.

[7] Wightman, W.P.D. (1953) The Growth of Scientific Ideas. Yale University Press. New Haven.

[8] Toynbee, A. (1963) A Study of History. Oxford University Press, New York.

[9] Giddens, A. (1990) The Consequences of Modernity. Stanford University Press, Stanford.

[10] Wallerstein, E. (2004) World Systems Analysis: An Introduction. Duke University Press, Durham.

[11] Watson, J.D. (1968) The Double Helix: A Personal Account of the Discovery of the Structure of DNA. Athenaeum, New York.

[12] McElhenry, V.K. (2010) Drawing the Map of Life. Inside the Human Genome Project. Basic Books, New York.

[13] Breskin, A. and Rudiger, V. (2009) The Cern Large Hadron Collider: Accelerator and Experiments. CERN, Geneva.

[14] de Solla Price, D.J. (1963) Little Science, Big Science. Columbia University Press, New York. 